\title{
Opis kozarjeve skodele v Teokritovi Prvi idili: realizem ali iluzija
}

Ključne besede: ekphrasis, enargeia, Teokrit, Idile, opisi likovnih umetnin, helenizem

DOI: 10.4312/ars.11.1.45-62

Dalje je ribič vrezljan, ob njem pa raskava skala, starec se trudi, da ribe ujel bi v mrežo ogromno.

Dobro poglej, kako na vso moč peha se in muja!

Skoraj bi rekel, da ribe lovi z vso silo telesa:

vsepovsod okoli vratu so mu žile nabrekle,

že ima sive lasé, a v moči se kosa z mladostjo! ${ }^{1}$

Najbolj znana ekfraza ${ }^{2} \mathrm{v}$ Teokritovi poeziji je opis kozarjeve skodele ${ }^{3} \mathrm{v}$ 1. idili z

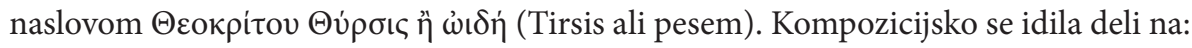
prolog (Idile, 1, 1-28), opis kozarjeve skodele (29-63), Tirsisovo pesem (64-142) in epilog (143-152). Prolog in epilog tvorita okvir pesmi, vanj pa sta vstavljena osrednja dela, opis posode in Tirsisova pesem, ki na ta način neposredno vzporejata likovno in pesniško umetnost ${ }^{4}$.

$\mathrm{V}$ pesnitvi nastopata dve osebi: pevec Tirsis in anonimni kozji pastir. Pred začetkom opisa kozar Tirsisu ponudi kozje mleko in umetelno rezljano skodelo kot darilo za pesem o Dafnisovi žalostni usodi (25-28). Na koncu opisa kozar, prevzet od

1 Odlomek iz ekfraze v Teokritovi Prvi idili (Idile, 1, 39-44). Prevod K. Gantar.

2 Izraz ekphrasis ( kiparskega izdelka, arhitekture ali predmeta. Vključuje tudi opis prostora, časa, oseb, dogodkov in celo prizore bitk. Najpogosteje se je izraz nanašal na literarni opis umetniškega dela, ki je bralcu ali poslušalcu »živo naslikal « podobo opisanega predmeta. Ekfraza, kot izraz slovenimo, je pomenila določeno pasažo v pesnitvi, dramskem ali proznem besedilu, ki je notranjemu ali zunanjemu recipientu (bralcu oziroma opazovalcu) izčrpno opisala določeno stvar. Več o pojmu ekphrasis v: Webb (2009, 17-19).

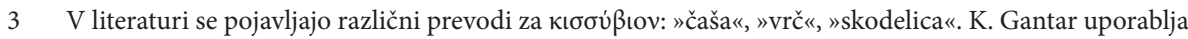
prevod »čaša«, sama pa sem se glede na razlago, pastirski milje in predloge iz vaznega slikarstva odločila za prevod »skodela«. Tudi Teokrit ni zelo natančen pri imenovanju kozarjeve posode: enkrat

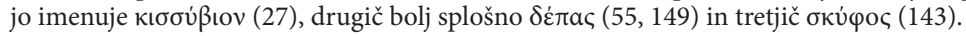

4 Članek je predelana verzija poglavja moje magistrske naloge $\mathrm{z}$ naslovom Opisi likovnih umetnin $\mathrm{v}$ helenistični poeziji. 
lepote umetnine, navede še izvor posode in ceno, ki jo je plačal zanjo (56-63). ${ }^{5}$ Sledi opis slik: rob skodele obroblja bršljanov venec; pod njim si sledijo tri žanrske slike: prva prikazuje spopad dveh tekmecev za žensko naklonjenost; na drugi je upodobljen stari ribič pri vsakdanjem težaškem delu; na tretji pa fantič v vinogradu, zatopljen v svoje opravilo, ter dve lisici, ki se smukata okoli brajd. Vsenaokrog je skodela okrašena $\mathrm{z}$ akantom (29-55).

Prvi osrednji del idile je opis reliefnih podob na kozarjevi skodeli. Opis sledi tradiciji, ki jo je začel Homer z opisom Ahilovega ščita (Iliada, XVIII, 478-608), ${ }^{6}$ sam opis predmeta pa nas spomni na opis Nestorjeve čaše v enajstem spevu Iliade (632637). Razlika med obema posodama je vidna že v samem imenu, materialu in obliki: vrč ( $\delta \varepsilon \dot{\pi} a \varsigma)$ je pri Homerju verjetno iz brona, štiriročen in s kovanima goloboma. Teokritova skodela ( podobami. Drugi osrednji del, Tirsisova pesem, ki je težišče idile, pripoveduje zgodbo o Dafnisu, legendarnem sicilskem pastirju, ki je veljal za začetnika pastirske poezije. Obstaja več različic njegove zgodbe. Dafnis ${ }^{7}$ je pasel črede na Siciliji. Vanj se je zaljubila nimfa. Dafnis se ali ni odzval njeni ljubezni ali se ji je izneveril. Od silnega trpljenja je sam izbral smrt. Po Teokritovi različici se je Dafnis bahal, da je nedovzeten za čare ljubezni, kot bi lahko sklepali iz verzov 95-98. Afrodita je za kazen v njem razvnela tako strast, da si je zaradi nesrečne ljubezni vzel življenje. Število prizorov na skodeli je, glede na Homerjev opis, omejeno na tri, število posameznih figur v prizoru pa zreducirano na tri $\mathrm{v}$ prvem, eno $\mathrm{v}$ drugem in znova tri $\mathrm{v}$ tretjem prizoru. $\mathrm{S}$ tem je vzpostavljena simetrija v zgradbi opisa: emblematična podoba ribiča v srednjem polju in dva trifiguralna prizora na vsaki strani. Iz pesmi težko razberemo, kje točno se vije akant, a verjetno obdaja slike na posodi. Zagotovo je rastlinski ornament brez figuralike nov likovni element, ki ga do zdaj v opisih še nismo zasledili (Friedländer, 1912, 14). Način postavitve posameznih figur spominja na Homerja, predvsem v prepiru dveh mož, ki sta tudi na Ahilovem ščitu, in v prizoru vinograda, obloženega $z$ grozdjem. Okoliščine prepira pri Homerju so precej drugačne, nanašajo se na plačilo za uboj in imajo zelo malo skupnega s prepirom dveh mož za žensko pri Teokritu.

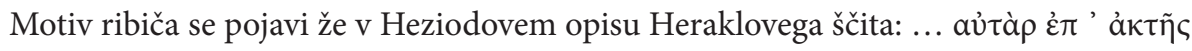

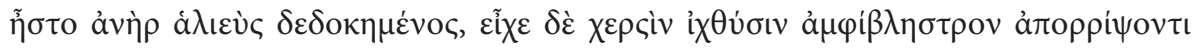

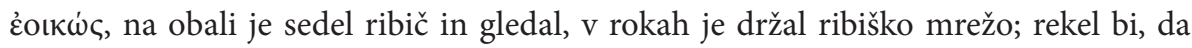

5 Pastirski agoni so značilna žanrska tema v Teokritovi bukolski poeziji. Nagrade za zmagovalca oziroma tekmovalca so preproste, primerne pastirskemu stanu. Največkrat je to hrana, pijača, pastirsko orodje, posoda, glasbilo ali žival. Skodela je bila namenjena v dar pastirju Tirsisu za pesem o Dafnisu.

6 Opis Ahilovega ščita s komentarjem: cf. Taplin (1980, 1-21).

7 Verjetno sin Hermesa in neke nimfe. Mati ga je odložila pod lovorov grm (dáphne), po katerem je dobil ime (Harvey, 1937, 131). 
jo bo pravkar vrgel (Sc. 213-215). ${ }^{8}$ Prizor v vinogradu nam znova prikliče v spomin prizor vinograda na Ahilovem ščitu. Oba pesnika opisujeta čas trgatve, Homer pravi:

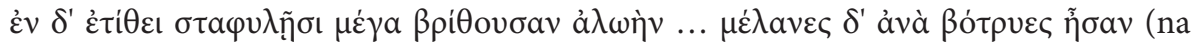
njem je napravil še vinograd, bogato obtežen od grozdja ... črno je bilo grozdje na

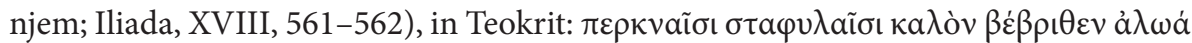
(vinograd dobro obložen od temnega grozdja, Idile, 1, 46). Podobnost stavkov je lahko naključn'a, a po načinu izražanja Teokritov opis ustreza Homerjevi dikciji opisa umetniškega izdelka (Gow, 1913, 221). Težko bi rekli, da Teokrit kot poznavalec epike ne bi poznal Homerjevega in Heziodovega ščita, ni pa jasno, ali se je želel na opisa neposredno navezati. Prizori ribištva imajo, kot bomo videli pozneje, tradicijo tudi v grški umetnosti in epigramu (prim. Leonidas iz Tarenta), zato je mogoče, da je pesnik navdih za osrednji prizor črpal iz določenega artefakta ali ikonografskega tipa (Gow, 1913, 221-222).

Glede na funkcijo opisa je obveljalo mnenje, da je opis spreten nadomestek, ki služi kot protiutež Tirsisovi pesmi. Izpostavljeno je vsakdanje življenje na deželi, za razliko od čustvenega boja pastirja Dafnisa z Afrodito, opisanega v Tirsisovi pastirski pesmi. Življenje na deželi je ponazorjeno z najznačilnejšimi situacijami: otrok pri igri, mladostna zaljubljenost in starost $\mathrm{z}$ vsemi tegobami preživetja. Očiten je kontrast med vizualnim opisom skodele s preprosto dikcijo in skromnimi slikovnimi detajli proti liričnemu tonu Tirsisove pesmi. Če gledamo opis s te perspektive, ravno realistična nota opisa kaže sofisticirano estetsko in tematsko sorodnost z drugo polovico idile (Zanker, 1981, 81). Nekateri menijo, da je imel pesnik v mislih določeno skodelo, prizore naj bi prenesel iz drugih umetniških del, dekoracija pa naj bi bila dodana po njegovi domišljiji (Gow, 1913, 207). Tudi glede postavitve samih prizorov so mnenja različna: nekateri vse prizore postavljajo na zunanjo stran posode med rastlinsko vegetacijo, drugi prizor ribiča postavljajo znotraj, tretji spet znotraj uvrščajo žensko s

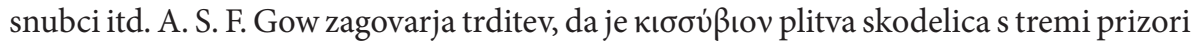

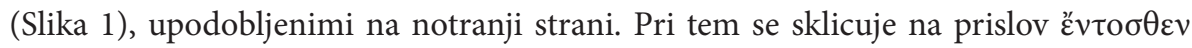

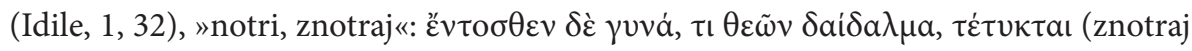
je vrezljana ženska, kakšna mojstrovina bogov) ter na simetrično ureditev slik znotraj posode $\mathrm{z}$ ribičem kot osrednjim prizorom $\mathrm{v}$ sredini na dnu in dvema prizoroma ob straneh (Gow, 1913, 207-222). 


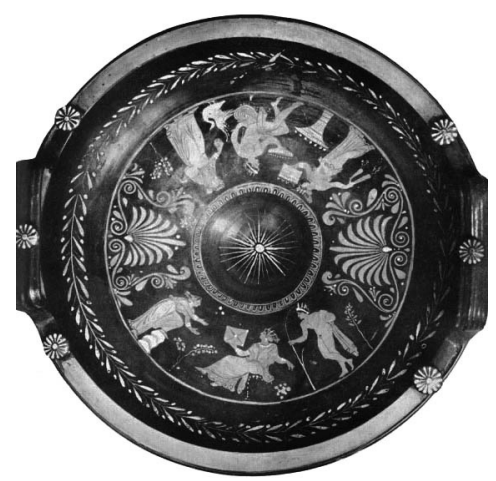

Slika 1: Grška fiala, Apulija, 4. st. pr. Kr., British Museum, London, inv. št. F 461. ${ }^{9}$

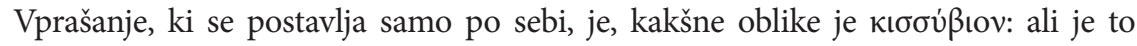
skodelica, čaša ali vrč in kje so locirani prizori glede na obliko posode. Proti Gowovim argumentom govori sintagma $\kappa a \tau^{\prime}$ aủtóv, »vzdolž«, ki v primeru, da so prizori znotraj posode, ostaja brez pomena. Če predpostavljamo, da so prizori na zunanji strani, imamo vrsto ornamentov, ki se vijejo vzdolž posode: bršljan z rumenimi plodovi zgoraj ter akant okrog in okrog, verjetno okrog samih prizorov. Nadalje lahko prislov

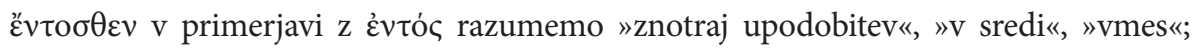

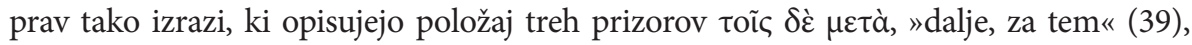
in $\tau u \tau \theta$ òv $\delta^{\prime}$ ö $\sigma \sigma o v$ ă $\pi \omega \theta \varepsilon v$, »malo naprej« (45), ne kažejo najbolj prepričljivo na postavitev središčnega prizora na sredino z obdajajočima prizoroma, razdeljenima $\mathrm{v}$ dve polji na straneh. Naravnejša se zdi domneva, da prizori tečejo drug za drugim na zunanji strani, ko posodo obračamo v roki. Vsekakor je razporeditev prizorov na posodi z dvema ročajema vredna razmisleka. Odvisno je tudi od tega, kako razumemo Teokritov opis, ali kot natančno vizualizirano umetniško delo ali kot plod umetnikove "fantazije« (Dale, 1952, 129). Petrain se pridružuje mnenju, da so slike, ki opisujejo tri človeška obdobja: otroštvo, zrelost in starostno dobo, postavljene na zunanjo stran posode, "znotraj« okvira vegetacije (Petrain, 2006, 258). Prav tako Mark Payne prvi ženski lik locira "znotraj«, ह̌v Izraze »znotraj«, »V sredi«, »dalje«, »malo naprej«, »poleg«, »z obeh strani«, »okrog«, ki prostorsko določajo ljudi z opisa, je bolje razumeti, pravi, kot dvodimenzionalne figure, človeške in živalske, $\mathrm{z}$ mišljenjem in čutenjem na površini skodele (Payne, 2007, 37-39). Opis prizorov se začne z zrelostnim obdobjem, sledi starost in na koncu prizor otroka pri igri. Časovno neskladje je očitno; Petrain predlaga, da bi ga utemeljili naratološko, $\mathrm{z}$ razlikovanjem med pojmoma fabula in siže. Pomembnejša od časovnega zaporedja prizorov (fabula) je pripoved sama (siže). Večji poudarek je na prostorski

9 Gow II (1952, slike 639: slika III). 
razporeditvi slik, ki prizorom človeškega življenja omogočajo, da se pojavljajo v poljubnem zaporedju, glede na to, kako posodo obrnemo. Gledalec lahko izbira, kje bo začel ali končal ogled (Petrain, 2006, 259). Pri opisu ne zasledimo središčnega prizora, iz katerega bi se nadaljevali ostali prizori (prim. Heraklov ščit). V krožni kompoziciji so vsi prizori enakovredni, brez začetka in konca (Petrain, 2006, 262). Kakršenkoli poskus rekonstrukcije skodele je vprašljiv, ker poskušamo ustvariti fizični predmet, ki ga morda nikoli ni bilo. Ali nam ni kozar povedal vsega, kar je mogoče »videti «? Posoda je pesniška iznajdba in zunaj pesnitve ne obstaja. Celo izraz kissubion pripada literarnemu jeziku in

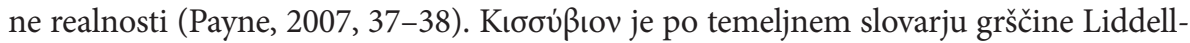
Scott-Jones (v nadaljevanju LSJ) »kmečka skodelica« oziroma »čaša za pitje«, izdelana iz lesa. Ime je dobila bodisi po bršljanovem lesu kot materialu, iz katerega je bila izdelana, ali bršljanovem vencu kot dekoraciji. Skodelica, pravi Teokrit, je "prelita s sladkim voskom« (27), »še diši od dleta« (28), kar dokazuje, da je lesena. Teokrit v opisu navaja

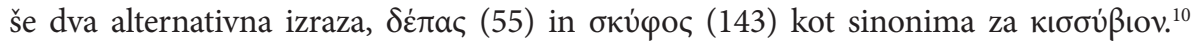
$\Sigma \kappa u ́ \varphi o \varsigma$ je globoko oblikovana posoda brez podstavka, ki zaradi globine znotraj ne more imeti reliefnih podob (Dale, 1952, 129). Obliki posode ustreza tudi Teokritov opis $\beta a \theta \dot{v}$

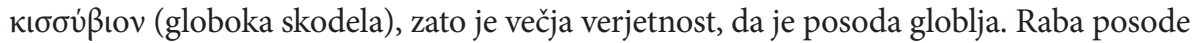
na podeželju je razvidna iz 16. speva Odiseje, ko se Telemah in Odisej srečata pri Evmaju

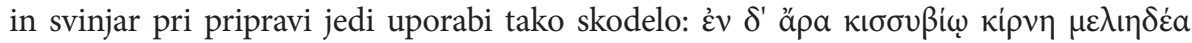
oľvov (v skodelo pa zmeša medeno vino, Odiseja, XVI, 52). Skodela, v kateri Odisej

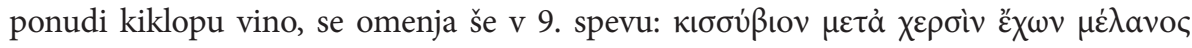
olvvoto (s skodelo v roki, napolnjeno s črnim vinom, Odiseja, IX, 346); predvidevamo,

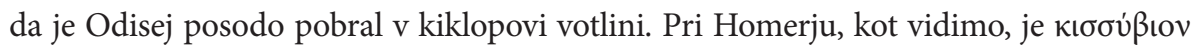
kar velika posoda, ne toliko v pomenu običajne čaše ali kupe, čeprav je namenjena pitju. Velikost, preproste oblike in kmečki milje so gotovo osnovne značilnosti, ki so veljale v 5. stoletju pr. Kr. Iz Homerjeve omembe pa nikakor ne moremo sklepati, da je

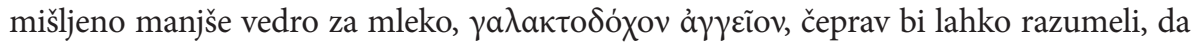

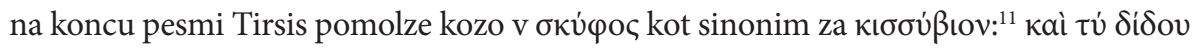

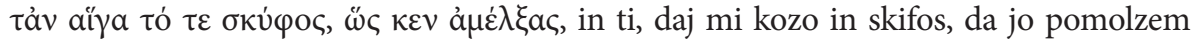

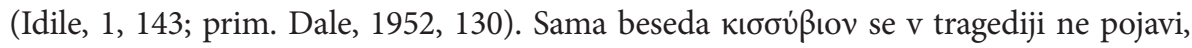

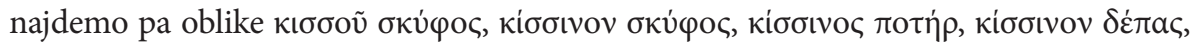

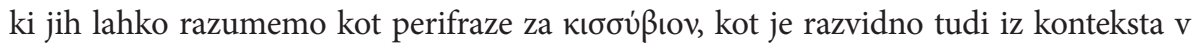

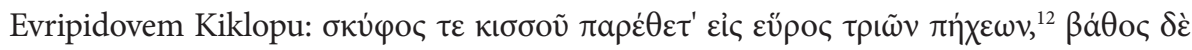

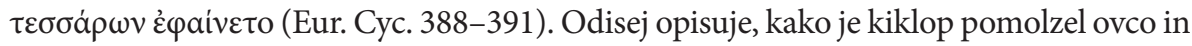

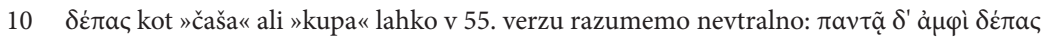

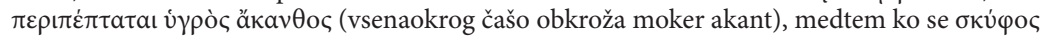

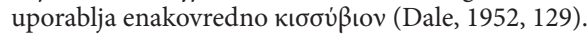

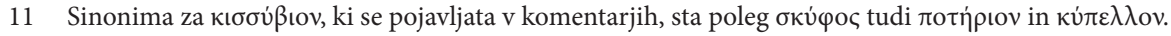

$12 \Pi \tilde{\eta} \chi \cup \varsigma$ kot mera od komolca do konca prstov $=46 \mathrm{~cm}$; skifos meri tri vatle $\mathrm{v}$ širino in štiri v globino, kar znova priča o njegovi velikosti. 
napolnil krater z mlekom, poleg postavil skifos z bršljana, tri vatle širok in štiri globok,

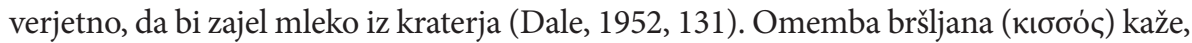
da naj bi bila posoda izdelana iz bršljanovega lesa. ${ }^{13} \mathrm{~A}$. M. Dale se upravičeno sprašuje o primernosti bršljanovega lesa, katerega deblo je preveč krhko, da bi bilo mogoče iz njega karkoli rezbariti, še zlasti večjo posodo. Mogoče je, da so pesniki uporabljali perifrazo

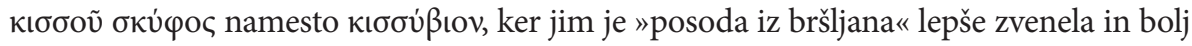
ustrezala jambskemu metrumu kot ime za »kmečko posodo«(Dale, 1952, 131). Teokrit je bršljan preobrazil v dekorativni motiv, ki obkroža rob posode, podobno kot kaže skifos iz 5. stoletja pr. Kr. Upodobljeni satiri sami po sebi asociirajo na Bakha oziroma Dioniza z bršljanom kot atributom (Slika 2).

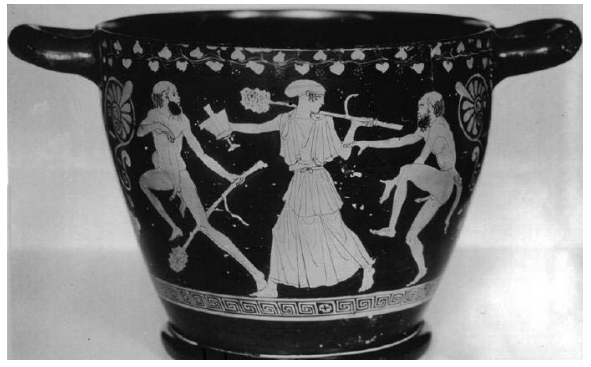

Slika 2: Menada s tirsom in kantarom v rokah med satiroma, levi ima prav tako tirs $\mathrm{v}$ roki, slikar Pentezileje, rdeče-figuralni skifos, 475-425 pr. Kr., Museum of Fine Arts, Boston (MA), inv. št. 01.8032. ${ }^{14}$

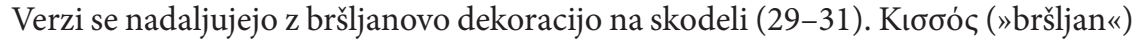

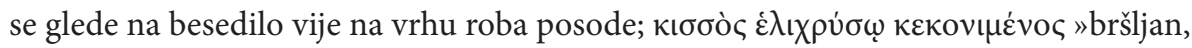
oprašen s helihrizom«: $\dot{\varepsilon} \lambda i x \rho v \sigma o v$ je helichrysum siculum, "zlatica«, po LSJ "goldflower «, cvetlica z ravnim, neupogljivim steblom, ki se vije okoli bršljana. Gow ime napačno razlaga kot bršljanov cvet, namesto roža z zlatimi cvetovi, ki, oprašena $z$

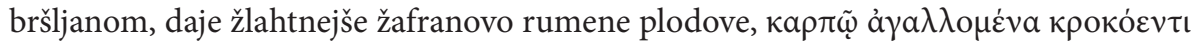
(Gutzwiller, 1986, 253); mišljen je zlato rumeni bršljan (hedera chrysocapra), za katerega so značilne zlato rumene jagode in živo zeleni listi, za razliko od črnih, ki jih ima naš navadni bršljan.

Bršljan je običajen atribut Dioniza in dionizičnih kultov: je v vseh letnih časih zelen ter simbolizira silo rasti in vztrajno poželenje.

V opisu izstopajo posamezni detajli. V prvem prizoru je upodobljena ženska z dvema moškima, ki ji dvorita (Idile, 1, 33-38). Kozar upodobitev ženske opiše kot mojstrovino,

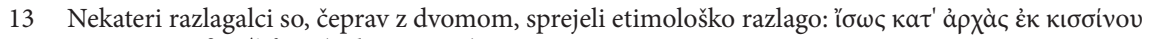

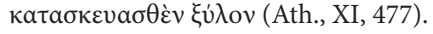

14 Slika 2 predstavlja skifos $\mathrm{z}$ dvema ročajema, na vrhu obdan z bršljanom, s poslikavami na zunanji strani - za približno predstavo o obliki posode, o kateri govori Teokrit. 


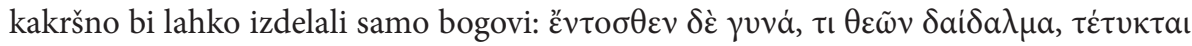
(znotraj je vrezljana ženska, kakšna mojstrovina bogov, 32 ). ${ }^{15}$ Ženska je oblečena v

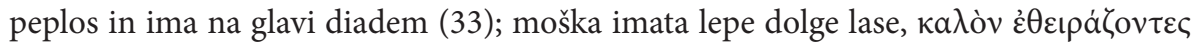

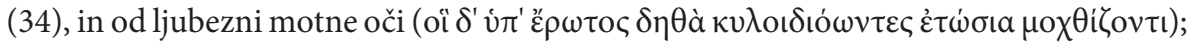
trudita se brez uspeha (37-38). Opis je zapolnjen z ravno pravšnjim številom detajlov, da si lahko bralec oziroma poslušalec zamisli prizor. S selektivnimi podrobnostmi je vključen element »enargeje« (živosti), ki apelira na »fantazijo« poslušalca, da si v domišljiji ustvari sliko (Zanker, 2004, 12). V opis je vključena tudi pripoved, uvaja jo

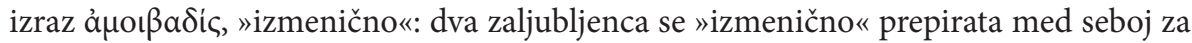

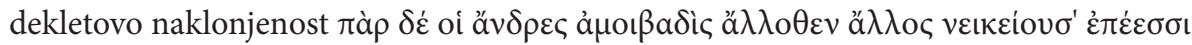
(zraven pa dva moža se menjaje prerekata drug na drugega, 33-35). ${ }^{16}$ Pripoved se nadaljuje v gibanje ženske, ki z nasmeškom obrača pogled zdaj v enega, zdaj v drugega

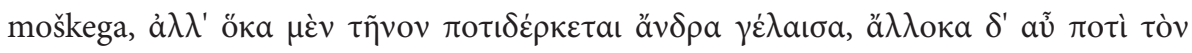

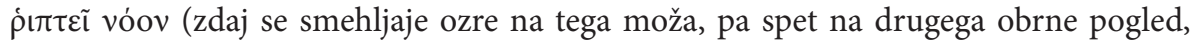
36-37). Ženska, kot razberemo iz besedila, sicer uživa v moškem rivalstvu, a se ne zmeni prav dosti za njuno dvorjenje. Nasmešek, ki ga poklanja moškima, je iluzoren in se konča brez uspeha ( $\dot{\varepsilon} \tau \omega \sigma \iota \alpha)$ za oba tekmeca. Kozarjev opis dejansko presega vizualno predstavitev; iz slike je naredil zgodbo, s tem ko je dodal časovno dimenzijo ter misli in emocije osebam s prizora (Payne, 2007, 33). Igra z nasmeškom nas, bralce, vabi v razmislek, da sami interpretiramo odziv ženske in s tem pomagamo dopolniti zgodbo (Zanker, 2004, 12). Kdo naj bi bila upodobljena ženska, »bogov mojstrovina«; podoba boginje, ustvarjena od bogov, ali umetniški izdelek po božjem navdihu. Lahko bi bila Pandora ali Pigmalionov ženski kip. Podobno »to pa ne gane njenega srca« (35) namiguje na več kot človeško ravnodušnost. Njen nasmeh nas spomni na Afrodito »S sladkim nasmeškom na ustih« ( $\gamma \varepsilon \dot{\lambda} \alpha \iota \sigma \alpha, 95-96)$, ki bo kasneje obiskala Dafnisa (Payne, 2007, 30-32). ${ }^{17} \mathrm{~V}$ trojici zaznamo tudi čustveno stanje: $\mathrm{v}$ ženskem lahkotnem

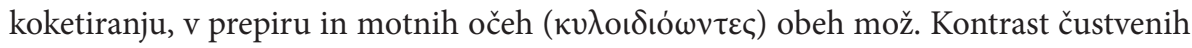
stanj je značilen za helenistično poezijo in umetnost (Zanker, 2004, 12). Prizor spominja na prizor iz mimosa, zvrsti, ki je na Teokritove idile tudi sicer vplivala.

Primer prepira dveh moških za žensko je upodobljen na freski iz Pompejev, ki prikazuje Brizeidin odhod (Slika 3) (Hughes Fowler, 1989, 7). Agamemnon se je bil prisiljen odpovedati deklici Hrizeidi, ki jo je imel kot vojni plen, in jo vrniti

15 V tem stavku dobimo asociacijo na inspiracijsko teorijo, ki jo je razvil Platon v dialogu Ion. Skozi Sokratova usta razloži, da je vir resničnega pesniškega ustvarjanja božansko navdihnjenje (enthousiasmós), ne pa veščina in človeški razum. Pesnik je zmožen pesniti samo to, kar mu narekujejo Muze (Ion, 533 d-534 e).

17 Nasmešek kot Afroditin atribut omenja že Homer v Odiseji: »ona odide na Kiper, smehljava gospa Afrodita« (Odiseja, VIII, 362). 
očetu, svečeniku Hrizu. Iz Ahilovega šotora je ukazal privesti lepo Brizeido ter s tem povzročil Ahilov srd in odhod iz boja. Vojna se je z Ahilovo odsotnostjo obrnila v korist Trojancev (Iliada, I, 335-350).

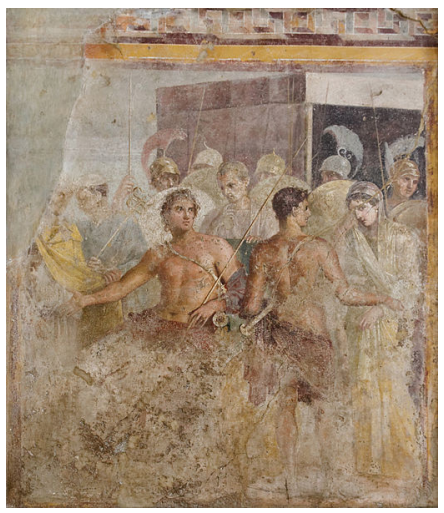

Slika 3: Brizeida odhaja od Ahila, freska iz hiše tragiškega pesnika v Pompejih, Museo Nazionale, Neapelj, inv. št. 9105.

Dosežek v upodabljanju je naturalistični nasmešek. Očarljiv primer je bronasti kipec dekleta iz Palazzo Grazioli v Rimu (Slika 4) (Hughes Fowler, 1989, 7).

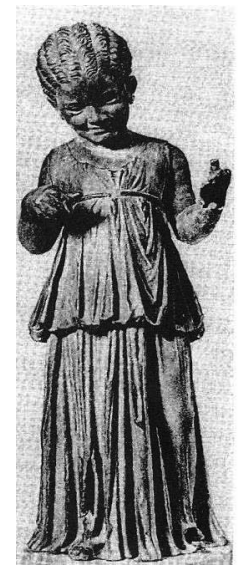

Slika 4: Smejoče se dekle, terakota, 3. st. pr. Kr., Palazzo Grazioli, Rim. ${ }^{18}$

Prizor ribiča je ravno tako opisan $\mathrm{z}$ vrsto detajlov: poudarjeni so ribičeva starost (39, 41, 45), sivi lasje (44), izčrpanost od morja (45), aktivnost, s katero se pripravlja na ulov (40), detajl izstopajočih žil na vratu, ko vleče mrežo (43), in raskava skala (39). Opisani trenutek ulova je ponovno podan tako, da si lahko bralec prizor v zavesti

18 V zgodnjem helenizmu, zlasti v Aleksandriji, so bile značilne terakotne »Tanagra « figurice. Ponavadi so predstavljale dekleta, zavita v plašče, prikazana v počasnem elegantnem gibanju (Bieber, 1981, 95). 
naslika (Zanker, 2004, 13). Pozornost vzbujajo interpretativni elementi »enargeje«: "poglej, kako se na vso moč napreza« (41); dalje je interpretacija naslovljena na Tirsisa in posredno na bralca, ko kozar komentira: »rekel bi, da ribe lovi z vso močjo udov, tako

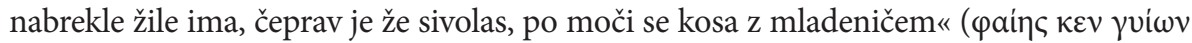

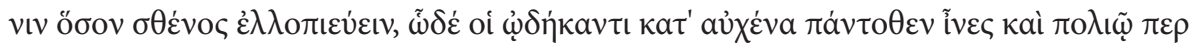

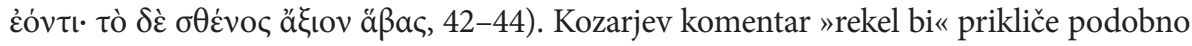
reakcijo iz 15. idile, ko ženski Gorgo in Praksiona občudujeta tkanine na Adonisovem praznovanju: »Rekel bi, da so obleke za same boginje, gospa Atena, kakšne ženske so jih stkale, kakšni umetniki so tako natančno naslikali like? Kakor resnični stojijo in se gibljejo kakor resnični, živi, ne stkani. Ljudje so res bistri« (Idile, 15, 79-83). Obe opazki

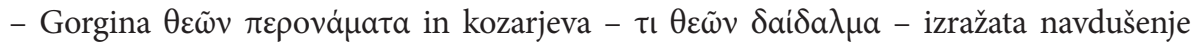
nad umetniškim izdelkom. Pomembnejša od samega predmeta je reakcija nanj (Payne, 2007, 34-35). Trenutek, v katerem je pesnik ujel starega ribiča z natančnim opisom muskulature, ima jasne vzporednice $\mathrm{v}$ vizualnih umetnostih helenističnega obdobja in v vseh žanrih helenistične poezije (Zanker, 2004, 13). Zanker v zvezi s tem govori o "slikovnem realizmu« (pictorial realism). Prepoznamo ga v motnem pogledu obeh mož

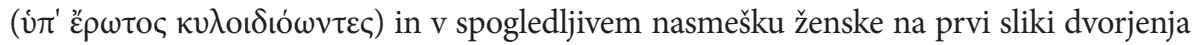

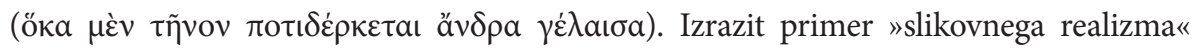
najdemo v podobi starega ribiča, ki so mu od težaškega dela nabrekle žile okoli vratu

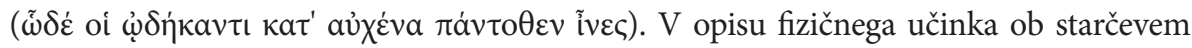
naporu je Teokrit neposredno ubesedil svojo moč opazovanja (Zanker, 1987, 80). Pesnik in prek njega kozar vabita še bralca, da s svojo "fantazijo « dopolni stopnjevani trenutek tik pred metanjem mreže (Zanker, 2004, 13). Vizualna predstava starega ribiča je lahko upodobljiva. V zadnjem verzu je kozar k sliki dodal "po moči se kosa z mladeničem « (44), kot da bi predvidel končni izid dogodka (Payne, 2007, 34).

Tretja, najdaljša slika je zapolnjena $z$ vrsto deskriptivnih elementov: obložen vinograd z modrim grozdjem, kamniti zid, na katerem sedi deček, ki varuje vinograd (46-48), ena lisica je opisana, kako v resnici pleni grozdje (48-49), druga pa medtem ko čaka na priložnost, da bo ukradla fantovo malico (50-51). Učinek »enargeje« se kaže v vedenju dveh lisic v vinogradu. Upodobitev na skodeli prikazuje lisici, ne pa njunega dejanja, o ka-

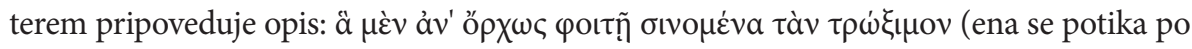

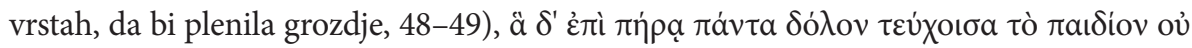

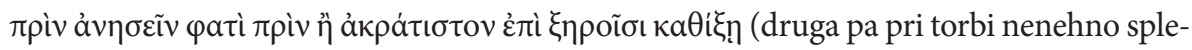
ta zvijačo in kaže, da dečka prej ne spusti, preden se sita od suhe hrane ne usede, 49-51). "Slikovni realizem« je izrazit v žanrskem motivu dečka, ki, zatopljen v delo, plete mre-

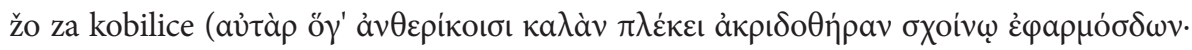

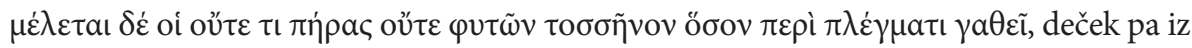
stebel plete čvrsto mrežo za lov na kobilice, z ločjem jo veže; ne zmeni se niti za torbo niti 
za grozdje, tako zelo je zavzet s pletenjem, 52-54). Besedilo tudi tukaj nagovarja bralca, da dopolni izid, ki ga predvideva pripoved: ena lisica bo nadaljevala z zobanjem grozdja do sitega, druga bo pojedla malico, medtem ko je fant zatopljen v svoje delo (Zanker, 1987, 14). Podobno kot pri prvih dveh slikah moč »fantazije« Teokritu omogoči ustvariti domišlijijko sliko in pripraviti pot interpretaciji, ki jo nakazuje vedenje obeh lisic. Vizualna prezentacija se s pripovedjo veliko bolj sklada kot na prvi sliki; opis vinograda in nameri lisic je mogoče upodobiti; podobno je $\mathrm{z}$ opisom izdelave mreže. $\mathrm{Z}$ dečkovo notranjo izkušnjo »ne zmeni se niti za torbo niti za grozdje, tako zelo je zavzet s pletenjem « (53-54) je kozar predstavil več, kot lahko vidimo, glede na drugo sliko (Payne, 2007, 36). Od vseh treh slik nas zadnji opis najbolj spomni, da imamo pred očmi iluzijo umetnine in ne realnega prizora (Gow, 1913, 219).

Med učinke »enargeje« sodijo tudi barve: žafranovo rumena barva bršljanovega plodu

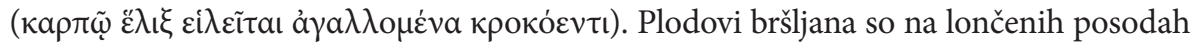
pogosto pobarvani rumeno, na srebrnih posodah pa je bršljan ponavadi pozlačen. $\mathrm{V}$ literarnem smislu lahko žafranovo barvo razložimo kot $\mathrm{v}$ mislih ustvarjeno podobo, vendar je večja verjetnost, da je v resnici rumen. Пoגıóc (»siv«, »osivel«) se lahko nanaša na sivo barvo ribičevih las, vendar se že pred Teokritom uporablja figurativno v pomenu

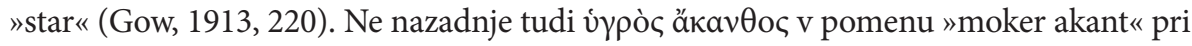
poslušalcu izzove »enargejo«. Upodobljen na izdelku kaže plastično podobo; ne smemo pozabiti, da naj bi bili prizori prikazani v reliefu. "Enargejo« ustvarjajo tudi slušne figure v opisih: aliteracija, asonanca in onomatopeja. Teokritova skodela je premazana

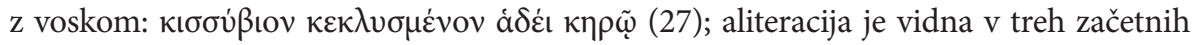
$\mathrm{k}$-jih, notranji $\sigma$ in asonanca $\mathrm{v} v$ tvorita mehki palatalni zvok. Aliteracija se pojavi tudi

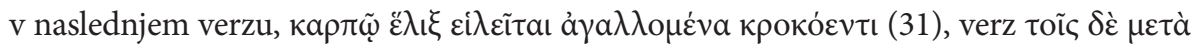

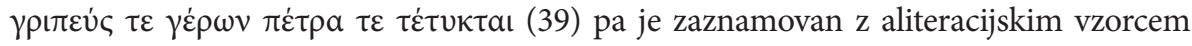
$\tau \ldots \tau \ldots \gamma \ldots \tau \ldots \gamma \ldots \tau \ldots \tau \ldots \tau \ldots \tau \ldots \tau ; \gamma \rho \iota \varepsilon \dot{v} \varsigma$ (»ribič») in $\gamma \varepsilon \dot{\varepsilon} \rho \omega \nu$ (»star«) sta poudarjena $s$

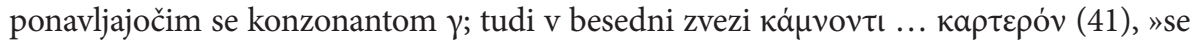
trudi« ... »močno«, je vidna aliteracija (Hughes Fowler, 1989, 13).

Zanker opozarja na pomembno razliko, pri kateri z mimesis ne moremo dovolj nazorno opredeliti realističnega opisovanja umetniških del v literaturi, ki ga on imenuje »slikovni realizem « (pictorial realism). Izraz za to vrsto realizma imenujemo enargeia (Zanker, 1987, 39). Pojem je definiral Dionizij Halikarnaški, ko je komentiral sposobnost govornika Lizija, da z opisom dogodka v bralčevi zavesti ustvari podobo in bralca spremeni v očividca oziroma gledalca (Lys. 7, 1-8). Po Dionizijevi definiciji je glavni namen dosežen s podobo oziroma sliko, ki jo poslušalec doživi. Govorniki so z izrazom enargeia označevali posebno odliko ekfraze. Grški govornik Hermogen jo razume kot "posebno jasnost «, ki naj bi prek slušnih zaznav povzročila vizualizacijo slike oziroma podobe (Spengel, Prog. 10, II, 16, 32). 
Pričevanja o izvoru pojma nas vodijo v 2. stoletje pr. Kr., ko se je termin v literarni kritiki uveljavil. Čeprav je pojav prisoten že v Homerjevih opisih (npr. Nestorjeva čaša ali Ahilov ščit) in ga nakazuje Simonidov izrek, da je pesništvo govoreče slikarstvo, kot je slikarstvo nemo pesništvo (fr. 557 PMG = Plutarh, Moralia, 346 F), ${ }^{19}$ se pri zgodnejših kritikih, Platonu, Aristotelu in Teofrastu, ne pojavlja kot predmet teoretske diskusije. Zato lahko povzamemo, da ima enargeia kot teoretski pojem v povezavi z realističnim opisovanjem umetnine zanesljivo helenistični izvor (Zanker, 1987, 41). Povezava med dvema umetnostma je v realistični nazornosti. Plutarh na poezijo gleda kot na posnemajočo umetnost, analogno slikarstvu, saj je obema cilj natančno prikazovanje predmeta, kot je videti $\mathrm{v}$ resnici, in vzbuditi v bralcu oziroma gledalcu emocionalni učinek poželenja (Plutarh, Moralia, 17 F-18 A).

Opisi starega ribiča in dečka v vinogradu na leseni posodi se ujemajo s sočasno težnjo $\mathrm{k}$ realizmu v likovni umetnosti. Ta je težila $\mathrm{k}$ upodabljanju naravnega in človeškega sveta brez idealizacije. Prvine realizma so od 4. stoletja pr. Kr. naprej čedalje bolj stopale v ospredje. Individualnost je za umetnike postajala mamljivejša kot iskanje popolnih oblik v Platonovem smislu. Prve napovedi »novega vala « so se kazale v izrazitejšem prikazovanju emocij, kot so bolečina, trpljenje, tesnoba, veselje in nežnost. Značilna je tudi erotična čutnost, še posebno v povezavi s stanji spanja in pijanosti: speči otroci, božanstva, heroji, pijani ali speči hermafroditi, satiri in pijane ženske. Pomembna vidika sta tudi upodabljanje individualne osebnosti v portretni umetnosti ter zanimanje za različne etnične in rasne skupine (Galci, Skiti, Afričani); to priča o kozmopolitskem duhu helenistične dobe. Tako kot je bilo srečevanje različnih ras v helenističnem svetu del vsakdana, so svoj vsakdan živeli tudi starka na tržnici, pijana ženska, izčrpan pastir ter ribič, izmučen od dela in revščine, preslikani $\mathrm{v}$ monumentalne podobe socialnega realizma (Pollitt, 1986, 141).

Sključena starka (Slika 5) z gubami na obrazu, brazdami na vratu in s povešenimi prsmi priča o realističnem slogu, ki dopolnjuje vsebino skulpture. Zdi se, da je prikazana med nagovarjanjem potencialnih kupcev na tržnici, v upanju, da bo prodala piščance ter vsebino košare s sadjem in zelenjavo, ki jo drži v levi roki. Bršljanov venec na glavi bi lahko nakazoval, da prodaja ali ponuja pridelke ob Dionizovem prazniku. Skulpturo štejejo za helenistični izvirnik (Pollitt, 1986, 142). Živosti v skulpturi starke ustrezata patos in sočutje do pijane ženske. Tudi to žensko povezujejo s kulturnim miljejem aleksandrijskega praznika. Vrč za vino, lágynos, ki ga drži v roki, se je uporabljal na kmečkih pivskih veselicah. Oblečena je v neke vrste tuniko, perónema ali perónetris, pritrjeno z zaponko, ki so jo nosile in občudovale obiskovalke ptolemajskega praznovanja $\mathrm{v}$ čast Adonisu, opisanega v Teokritovi 15. idili (Idile, 15, 21 in 79). Obleka staro žensko kljub pijanosti uvršča v višji družbeni razred, kamor spadata tudi ženski iz opisane pesmi.

19 Značilen primer »enargeje« pri Simonidu je fragment o Danai, fr. 543 PMG. 
V tem pogledu se razlikuje od pastirjev, ribičev in starih ljudi, predstavljenih v tem žanru (Slika 6) (Pollitt, 1986, 142). Patos razberemo tudi na obrazu starega ribiča. Ekspresivna podoba nam kaže moža, kot da brede po plitvi vodi, da bi vrgel mrežo. Ohranjenih je veliko kopij z motivom ribiča, najimpresivnejša je skulptura iz Louvra (Slika 7; Pollitt, 1986, 142-144). Oslabljeno telo z nabreklimi žilami nas spomni na sliko onemoglega ribiča na posodi iz 1. idile. Mogoče je, da je imel ta tip predhodnike v Teokritovem času. Teokrit se očitno navezuje tudi na žive likovne tradicije (Hunter, 1999, 77).

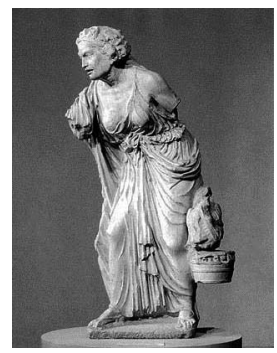

Slika 5: Starka, marmor, pozno 2. ali zgodnje 1. st. pr. Kr., New York, Metropolitan Museum, višina 1,26 m.

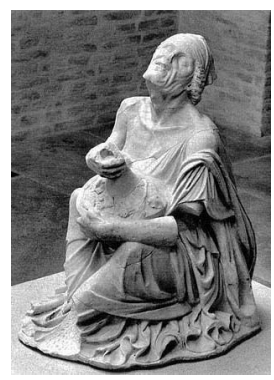

Slika 6: Pijana ženska, marmor, rimska kopija izvirnika dvomljive datacije, pozno 3. ali, verjetneje, pozno 2. st. pr. Kr., München, Gliptoteka, višina 0,92 m.

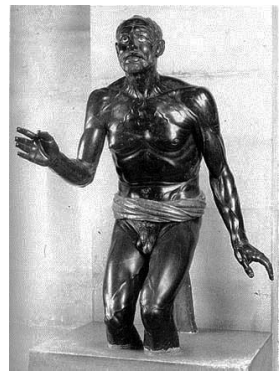

Slika 7: Stari ribič, črni marmor z oblačilom iz alabastra (deli obraza in roke so restavrirani), rimska kopija izvirnika dvomljivega datuma, verjetno $200-150$ pr. Kr., Pariz, Louvre, višina 1,22 m. 
Verjetno ena boljših Teokritovih ilustracij ribiča je cizelirana podoba na bronasti fiali v Britanskem muzeju. Na vrhu posode je v središču upodobljen mož z mrežo, ki jo bo ravno vrgel, spodaj nasproti pa je naslikan ribič z mrežo, polno rib (Slika 8; Walters, 1899, 164).

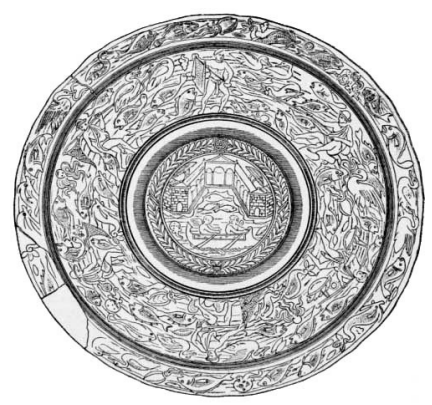

Slika 8: Bronasta fiala, verjetno sredina 2. st., British Museum, inv. št. 884.

Igrivost fanta $\mathrm{v}$ vinogradu pri izdelavi mreže za kobilice prepoznamo v razposajenem boju dečka z gosko (Slika 9) (Hughes Fowler, 1989, 14). To je ena najbolj občudovanih upodobitev otrok v antiki. Goske so imeli v antiki za hišne ljubljenčke, zato je mogoče, da deček svojo žival stiska s podobno vdanostjo in toplino. $\mathrm{V}$ helenistični umetnosti imajo torej svoje mesto tudi ljubki prizori otrok z živalmi: dečkov z gosko ali kužkom, deklic z golobom itd.

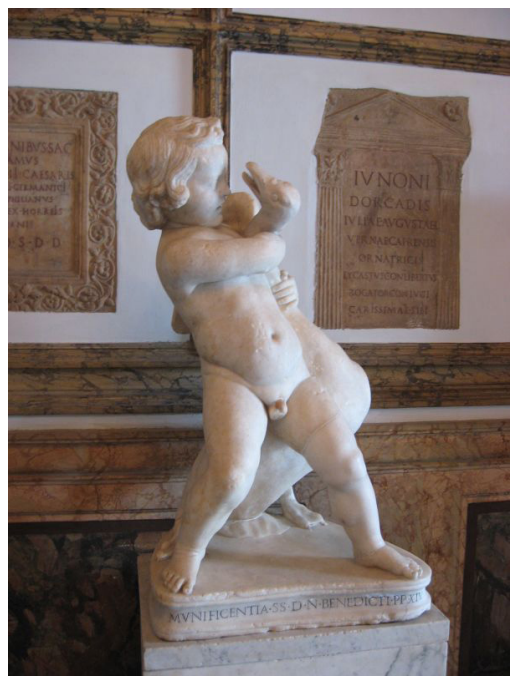

Slika 9: Deček v boju z gosko, marmor, rimska kopija, verjetno ok. 150 pr. Kr., Rim, Museo Capitolino, višina 0,85 m. 
Antična literarna kritika in retorika opisu nikoli nista namenjali avtonomne vloge. Funkciji opisov se je natančneje posvetila šele naratološka teorija v 20. stoletju. V besedilih, pravi Mieke Bal, ni vedno jasno, kateri deli so opisni (Bal, 1999, 36). Podobno je Genette prišel do zaključka, da enotnega pojma, ki ga Platon in Aristotel imenujeta diegesis, ne smemo cepiti. Opis ima, kot meni, narativno-deskriptivni značaj, čeprav je opisovanje samo eden od vidikov pripovedovanja (Genette, 1974, 1408). Če opis pomeni mejo pripovedi, je ta notranja meja precej nedoločljiva. Ekphrasis pomeni nekakšno prekinitev v pesnitvi, ki je lahko nedoločljiva kot pri Homerju, ko se pripoved kar nadaljuje v opis. Ahilov ščit nastaja v procesu izdelave (Bal, 1999, 37). Serija prizorov prikazuje ves bivanjski prostor homerskega človeka. Najizrazitejše podobe na njem so podobe miru in podobe iz vsakdanjega življenja, ki so v temeljnem kontrastu s temo epa. Teokritov opis se od Homerjevega temeljito razlikuje. Opis, ki ima neposredno zvezo z okvirno zgodbo, je verjetno izvirna iznajdba helenističnih pesnikov (Manakidou, 1993, 125).

Balova navaja tri možne načine, kako so opisi motivirani oziroma vstavljeni $\mathrm{v}$ pripoved. Motivacijo lahko dosežemo $\mathrm{z}$ opazovanjem $\mathrm{v}$ smislu žariščenja, $\mathrm{z}$ izdelovanjem ali govorom (Bal, 1999, 37). ${ }^{20}$ Navzočnost opazovalca pri literarnih opisih ni novost. Enej na začetku Eneide (Eneida, 1, 450-93) strmi v bojne prizore iz trojanske vojne, naslikane na stene Junoninega templja v Kartagini. Sliko gledata tudi Hajrea in Pamfila v Terencijevem Evnuhu (584-589). Druga oblika motivacije (izdelovanje) je najizrazitejša v opisu Ahilovega ščita. Hefajst opisani predmet dejansko ustvarja pred očmi bralca, čeprav je pri izdelavi orožja prisotna tudi Tetida. Opis je v tem pogledu popolnoma narativen. Drugačna motivacija pa nastopi v primeru, ko literarni lik ni več le priča, ampak to, kar vidi, tudi dejansko opisuje. Govorna situacija terja poslušalca. Pri Teokritovem opisu je kozar intradiegetski opisovalec skodele, Tirsis pa poslušalec, zato je prehod s sintagmatične ravni na paradigmatično po Homerjevem zgledu manj očiten. Glede na retorično definicijo ekphrasis, po kateri je ekfraza »opisni govor«, je opis kozarjeve skodele govor. Tudi Sławinskemu se je zdelo, da so opisi podobni govoru. Po njegovem mnenju opisi posedanjajo zgodbo in prikazani svet približajo čutno udeleženemu bralcu (Sławiński, 1982, 31-35).

Če vse tri slike povežemo v celoto, se izkaže, da je njihov pomen tudi metaforičen. Podrobnejša analiza slikovnih elementov na skodeli - bršljana kot simbola življenja in plodnosti, dveh moških, ki se spopadata za naklonjenost ženske, ribiča, ki kljub starosti vztraja pri delu, in dečka pri igri - lahko vodi tudi k interpretaciji, po kateri so podobe na skodeli metafora za življenjsko vztrajnost nasproti smrti, ki jo v tej pesmi izbere Dafnis.

20 Motivacija poteka na ravni besedila, ko lik sam opisuje predmet - na ravni pripovedi je to opazovanje lika -, na ravni fabule (kot osnovne strukture pripovedi) pa, ko lik opravlja dejanje v zvezi s predmetom opisa (Bal, 1999, 38-39). 


\section{Bibliografija}

Bal, M., Narratology: introduction to the theory of narrative, 2. izdaja, Toronto, Buffalo, London 1999.

Becker, A. S., Reading Poetry through a Distant Lens: Ecphrasis, Ancient Greek Rhetoricians, and the Pseudo-Hesiodic "Shield of Heracles", The American Journal of Philology 113.1, 1992, str. 5-24.

Bieber, M., The Sculpture of the Hellenistic Age, revid. izdaja, New York 1981.

Dale, A. M., KI $\Sigma \Sigma$ YBION, CR 2.3/4, 1952, str. 129-132.

Dionysius of Halicarnassus, The critical essays in two volumes, Vol. I, with an English translation by Stephen Usher, London, Cambridge (MA) 1974 (The Loeb Classical Library).

Friedländer, P., Johannes von Gaza und Paulus Silentiarius. Kunstbeschreibungen justinianischer Zeit, Leipzig, Berlin 1912.

Genette, G., Granice priče, Teka 6 (1974), str. 1403-1416.

Gow, A. S. F., The cup in the first idyll of Theocritus, The Journal of Hellenic Studies 33, 1913, str. 207-222.

Gow, A. S. F. (ur.), Theocritus, edited with a translation and commentary by A. S. F. Gow, Vol. I: Introduction, text, and translation, Cambridge 1952.

Gow, A. S. F. (ur.), Theocritus, edited with a translation and commentary by A. S. F. Gow, Vol. II: Commentary, appendix, and plates, Cambridge 1952.

Gutzwiller, K. J., The plant decoration on Theocritus' ivy-cup, American Journal of Philology 107, 1986, str. 253-255.

Harvey, P. (ur.), The Oxford Companion to Classical Literature, Oxford 1937, str. 131.

Hughes Fowler, B., The Hellenistic Aesthetic, Bristol 1989.

Hunter, R. (ur.), Theocritus. A selection. Idylls 1, 3, 4, 6, 7, 10, 11 and 13, Cambridge 1999.

Manakidou, F., Beschreibung von Kunstwerken in der hellenistischen Dichtung: ein Beitrag zur hellenistischen Poetik, Stuttgart 1993 (Beiträge zur Altertumskunde; Bd. 36).

Petrain, D., Moshu's Europa and the narratology of ekphrasis, v: Beyond the canon, Harder, M. A., Regtruit, R. F. Wakker, G. C. (ur.), Leuven, Paris, Dudley MA 2006 (Hellenistica Groningana; 11), str. 249-270.

Plutarch's Moralia, Vol. IV, with an english translation by Frank Cole Babbitt, London, Cambridge (MA) 1957 (The Loeb Classical Library).

Payne, M., Theocritus and the invention of fiction, Cambridge 2007. 
Pollitt, J. J., Art in Hellenistic Age, Cambridge 1986.

Publij Terencij Afričan, Evnuh, prevedel K. Gantar, Maribor 1987 (Iz antičnega sveta 26).

Sławiński, J., O opisie, v: Studia o narracji, pod redakcją Jana Błońskiego, Stanisława Jaworskiego, Janusza Sławińskiego, Wrocław 1982 (Z dziejów form artystycznych w literaturze polskiej; tom 59), str. 31-35.

Spengel, L. (ur.), Rhetores Graeci, Vol. II, Leipzig, 1883-1886.

Taplin, O., The Shield of Achilles within the Iliad, Greece \& Rome 27.1, 1980, str. 1-21.

Teokrit, Idile, prevodi ter opombe in razlage k pesmim K. Gantar in J. Mlinarič, spremna beseda J. Mlinarič, Maribor 1984 (Iz antičnega sveta 23).

Vergil, Eneida, prevedel F. Bradač, Ljubljana 1992 (Zbirka Svetovni klasiki 11).

Walters, H. B., Catalogues of the bronzes, Greek, Roman, and Etruscan in the Department of the Greek and Roman Antiquities, British Museum, London 1899.

Webb, R., Ekphrasis, imagination and persuasion in ancient rhetorical theory and practice, Farnham, Burlington 2009.

Zanker, G., Enargeia in the Ancient Criticism of Poetry, Rheinisches Museum 124, 1981, str. 297-311.

Zanker, G., Realism in Alexandrian Poetry: literature and its audience, London 1987.

Zanker, G., Modes of Viewing in hellenistic Poetry and Art, Madison, WI 2004 (Wisconsin studies in classics). 


\section{Opis kozarjeve skodele v Teokritovi Prvi idili: realizem ali iluzija}

Ključne besede: ekphrasis, enargeia, Teokrit, Idile, opisi likovnih umetnin, helenizem

Opis skodele v Teokritovi Prvi idili je vrivek, ki pa ni zgolj dekorativen, ampak je integralni del pesnitve. Notranja meja, ki opis loči od pripovedi, je nedoločljiva. Skodela je izdelana iz lesa in ima na zunanji strani izrezljane tri slike v linearnem zaporedju. Na prvi sliki sta upodobljena moška, ki tekmujeta za žensko naklonjenost, na drugi je stari ribič, ki lovi ribe, na tretji pa deček v vinogradu, ki plete mrežo za kobilico. Motivno in slogovno se opis navezuje na starejšo tradicijo; prizora tekmecev in vinograda najdemo tudi na Ahilovem ščitu. Pri analizi besedila sem izhajala iz retorične tehnike ekphrasis: »Ekfraza je opisni govor, ki živo privede pred oči to, kar se opisuje« (Spengel, Theon, Prog. 11, 239). V ospredje stopa ideal žive nazornosti (enargeia), ki opis spremeni v ekfrazo oziroma pri bralcu ali poslušalcu doseže iluzijo slike. Pomembno vlogo imajo barve in material, iz katerega so narejeni izdelki (rumeni cvetovi, sivi lasje, temno grozdje, lesena skodela). Ločiti moramo »enargejo« kot predstavljivost same slike in »enargejo«, ki jo v opisu dosežemo z besednimi učinki. »Enargejo« je mogoče stopnjevati z opisom gibanja, dejanj, misli in nagibov v pripovednih delih, npr. $\mathrm{z}$ aliteracijo in asonanco.

Ali gre za opis realne ali fiktivne umetnine? Opis se navezuje na konkretne ikonografske tipe in posnema nekatere estetske težnje likovnih predlog, vendar gre obenem za ustvarjalen literarni konstrukt, ki se navezuje na retorično-filozofsko teorijo o domišljijski upodobitvi, phantasia. "Slikovni realizem« tega opisa sledi težnjam pozne klasične dobe. Pesnik se pri opisu osredotoči na bistvene elemente zgodbe, ker predvideva, da poslušalci/bralci poznajo vsebino. Poleg tega se Teokritov opis ne omejuje na vprašanje »vizualnega« v besedni umetnini, temveč pripoved komentira. $\mathrm{V}$ tem kontekstu je mogoče opis razumeti kot metaforo za življenjsko vztrajnost nasproti smrti, ki jo v tej pesmi izbere Dafnis. 


\section{The Description of the Goatherd's Cup in Theocritus' First Idyll: Realism or Illusion?}

Keywords: ekphrasis, enargeia, Theocritus, Idylls, descriptions of works of art, Hellenism

Rather than mere decoration, the description of the cup inserted into the First Idyll by Theocritus is an integral part of the poem, as there is no clear-cut line separating the description from the main narrative. The cup is said to be made of wood, with three linear carvings on the outside. The first carving presents two men vying for a woman's favour, the second an old fisherman, and the third a boy in a vineyard, weaving a net for locusts. Since the rivalry and vineyard scenes are also found on the shield of Achilles, these motifs and the style of the description appear to draw on an older tradition in poetry. My analysis of the text is set in the framework of ekphrasis, a rhetorical technique defined in Ancient Greek rhetorical handbooks as "a descriptive speech that brings the subject shown before the eyes with visual vividness". What transforms a description into an ekphrasis, that is, what conjures up for the reader or listener the illusion of an actual object, is the ideal of visual vividness, or enargeia. An important role here is assigned to the colours and materials of the art work (yellow blossoms, grey hair, dark grapes, wooden cup). There are two kinds of enargeia: the capacity of visualisation inherent in the picture itself, and the same capacity as attained through the verbal effects of the description. The enargeia may be enhanced by descriptions of movements, actions, thoughts and impulses in narratives, as well as by such sound devices as alliteration and assonance.

Is the art work described real or imaginary? While the description does echo real iconographic types and aesthetic tendencies, it is at the same time a creative literary construct drawing on the rhetorical and philosophical theory of imaginative depiction, phantasia. The "pictorial realism" of the description follows the trends of the Late Classical period. As the audience is assumed to be familiar with the content, the description focuses on the essential elements of the story. Moreover, Theocritus' description is not limited to the "visual" aspect of a verbal artwork but also comments on the narrative. In this context, the description may be read as a metaphor for vitality - in contrast to death, as chosen by Daphnis. 